\title{
The Effectiveness of Online Learning Media on High School Students' Learning Interest with Information and Communication Technology Subjects
}

\author{
Yehezkiel Yoel Aelthea ${ }^{1}$, Sinta Paramita ${ }^{1}$, Sisca Aulia $^{1 *}$ \\ ${ }^{1}$ Faculty of Communication, Universitas Tarumanagara, West Jakarta 11440, Indonesia \\ ${ }^{*}$ Corresponding author. Email: siscaa@fikom.untar.ac.id
}

\begin{abstract}
This study aims to determine the effectiveness of online learning media on the learning interest of Don Bosco 1 High School students in the subject of Information and Communication Technology in 2020. Literatures used in this study are interest in learning, effectiveness, technology acceptance model. The approach used in this research is a quantitative approach with descriptive and survey methods. This research was conducted by distributing questionnaires to 100 respondents, namely students of Don Bosco 1 High School, after which the data obtained was tested for its validity by a validity and reliability tests. The technique of processing and analyzing data in this study used the correlation coefficient analysis test and the test because researchers wanted to know whether or not the relationship between one variable was strong. Correlation coefficient data can only be used if the significance test has been carried out.
\end{abstract}

\section{Keywords: Online Learning Media, Learning Interest, Information and Communication Technology}

\section{INTRODUCTION}

The corona virus or COVID-19 is a new virus that was discovered in Wuhan, China in December 2019. This virus originated from Wuhan residents who consumed wild animals such as bats. In March 2020 this contagious virus entered Indonesia and caused many aspects to be affected, one of which was the aspect of education, as a result schools had to be temporarily closed, not allowed to operate and replaced with online learning starting from March 16, 2020 (mediaindonesia.com, 2020). It is dire to master the science of technology for a teacher so that distanced learning continues to run effectively during the current COVID-19 pandemic. Teachers must also make innovations in learning by utilizing technology in learning to lift students' interest in learning online. Some of the teachers conducted learning using online media such as Whatsapp, Google Meet, Zoom, Ms. Teams, etc. The selection of applications used during online learning is also quite important to remember to make it easier to help in teaching. Don Bosco 1 High School's Information and Communication Technology lessons uses Microsoft Teams.

Don Bosco 1 High School is one of the schools to not be allowed to operate offline due to the pandemic. At the beginning, Don Bosco 1 High School's students were instructed to study at home and had its own difficulties in the attempts of doing so from both its teaching and learning aspects. Conducting online learning is a new experience for Don Bosco High School 1. regarding Information Technology subject, itself had a little difficulty in technical matters such as networking and not all students having sufficient internet data required for online learning and student adaptation using applications. In one of the lessons, Information and Communication Technology (ICT) uses online learning media, namely Microsoft Teams. Online learning media currently plays an important role for schools in the current pandemic condition. Microsoft Teams is described as a tool used to produce, process, reproduce and distribute information to convey.

Microsoft Teams is a service and communication application in the form of video calls with a maximum capacity of 100 participants the first time this application is launched. During this pandemic, Microsoft Teams made updates by increasing its capacity to 250 participants, besides that Microsoft Teams also guaranteed the safety of its users in using this application (Microsoft.com, 2017).

Regarding distance learning, it is also important to master the science of technology for a teacher so that distance learning can continue to run effectively in the current era. Teachers must also innovate in conducting online teaching in order to lift students' interest in learning.

According to Hurlock in [1] Rahmanto, interest is a source of encouragement to do something without coercion and is able to make a feeling of pleasure when doing an activity. Which means that interest in learning is an individual tendency to have a sense of pleasure and without coercion in learning. The teacher's function in teaching using new media plays an important role in building student interest in learning.

Based on the changes in teaching methods carried out by schools from conventional to online, the author wants to conduct research with the title "the effectiveness of online 
learning media on the learning interests of Don Bosco 1 high school students in Information and Communication Technology subjects in 2020".

\subsection{Hypothesis}

$\mathrm{H}_{0}$ : There is no relationship between the effectiveness of online learning media and the learning interest of Don Bosco 1 High School students in Information and Communication Technology in 2020.

$\mathrm{H}_{1}$ : There is a relationship between the effectiveness of online learning media and the learning interest of Don Bosco 1 High School students in Information and Communication Technology in 2020.

\subsection{Related Work}

\subsubsection{The Effectiveness of Using Web-Based E- Learning Media in Technology and Communication Learning on the Learning Results of Class X Students of Negeri 1 Kalasan High School}

[2] This research journal was written by Mawar Ramadhani from the Institute of Informatics Engineering, Yogyakarta State University in 2012. This research discusses how the effectiveness of using web-based e-learning media in information and communication technology lessons on the learning outcomes of class x SMA Negeri 1 Kalasan. concluded that the use of web-based e-learning has a higher effect than using conventional learning media. The equation in this study is to use the effectiveness of instructional media as variable $\mathrm{x}$.

\subsubsection{Effect of Electronic Word of Mouth, Level of Consumer Confidence and Interest in Culinary Sites Visits in Bogor City}

[3] This research journal was written by Teresia Ria Kristanti and Rezi Erdiansyah from the Faculty of Communication Science, Tarumanagara University in 2020. The problem faced in this study is whether there is an effect of electronic word of mouth, the level of consumer confidence and interest in visiting Bogor culinary sites. The conclusion in this study, namely the number of positive electronic word of mouth about Bogor culinary tourism creates consumer confidence and increases interest in making culinary sites. In this study, the equation is using interest as the $\mathrm{Y}$ variable and using quantitative type research.

\subsubsection{The Effectiveness of Using the Quizizz Application in Online Learning Physics on Business Materials And Energy Class X MIPA at Masehi Kudus High School 2019/2020 Academic Year}

[4] This journal is written by Yoselia Alvi Kusuma from Mathematics and Natural Sciences Education, Sanata Dharma University Yogyakarta. This study discusses how the effectiveness of using Quizizz media in closing online learning activities of physics business material and energy in terms of student responses by having the subject of class X MIPA students at SMA Masehi Kudus in the 2019/2020 academic year with quantitative methods. The conclusions drawn in this study are the use of quizzes media in the closing activities of online physics learning for class $\mathrm{X}$ MIPA at SMA Masehi Kudus running effectively, this is shown by a presentation of $91.30 \%$ and has the same type of quantitative, using effectiveness. media, using students of a school as the subject of the research.

\section{BACKGROUND}

\subsection{Effectiveness}

[5] According to Mardiasmo, effectiveness is a measure in determining whether or not there are goals in an organization, if an organization succeeds in achieving its goals, the organization runs effectively.

\subsection{Learning Media}

[6] According to Azhar learning media is a means doing a lesson that can stimulate students to learn because it contains instructional material so that students can do learning anywhere.

\subsection{E-Learning}

[7] According to Ardiansyah, e-learning is a learning system that can be done online between teachers and students and can be done anywhere. Based on the above statement, it can be concluded that online learning media is a means of communication in the form of audio visuals used in spreading ideas, ideas or opinions so that these ideas or opinions can reach the recipient where they will not work without the help of conveying messages or media.

\subsection{Interest to Learn}

[8] According to Witherington in Rahmanto, interest is an individual's awareness of doing something. If the individual does not have awareness of an object, the individual has no interest in that object.

[9] According to Djamarah, learning is an activity carried out by individuals to gain experience and can change individual perceptions so that it can change individual 
behavior in doing something, Meanwhile, [10] according to Hamalik. learning is not a goal but a process to achieve goals. Learning is modifying or reinforcing behavior through experience.

Thus, can be concluded that the notion of interest in learning is the tendency of individuals who have a sense of pleasure without coercion and to have a constant tendency to pay attention about something that is learned continuously, there is a feeling of liking for something they are interested in so that it can lead to changes in knowledge, skills and knowledge behavior.

\subsection{Technology Acceptance Model (TAM)}

The Technology Acceptance Model introduced by Davis in 1989 is an adaptation of the Theory of Reasoned Action (TRA) which is devoted to modeling user acceptance of technology. TAM is a model that can be used to analyze the factors that influence the acceptance of an information system or system. In the use of information systems, users consider the benefits and uses of the system. Venkantesh modified the TAM model by adding a trust variable with the title Trustenhanced Technology Acceptance Model, which examines the relationship between TAM and trust variables. Another modification was made by Liu and Jamieson in Jogiyanto (2007), namely the Trust and Risk in Technology Acceptance Model using the trust and risk variables together with the TAM variable. TAM is a theory that shows how individuals can understand and can use an information technology.

\section{OPERATIONALIZATION OF VARIABLES}

Table 1 Operationalization of Variables

\begin{tabular}{|c|c|c|c|c|}
\hline No. & Variable & Dimensions & Indicator & Scale \\
\hline \multirow[t]{4}{*}{1} & $\begin{array}{l}\text { Online Learning } \\
\text { Effectiveness }\end{array}$ & $\begin{array}{l}\text { a. Teacher Ability in } \\
\text { Processing Learning }\end{array}$ & $\begin{array}{l}\text { 1. how complete the } \\
\text { teacher is in } \\
\text { providing lesson } \\
\text { material } \\
\text { 2. How clear is the } \\
\text { teacher in giving } \\
\text { explanations }\end{array}$ & $\begin{array}{l}\text { Likert } \\
\text { Likert }\end{array}$ \\
\hline & & b. Student Activities & $\begin{array}{l}\text { 1. I followed the } \\
\text { teacher's explanation } \\
\text { carefully in the } \\
\text { Information and } \\
\text { Communication } \\
\text { Technology lesson } \\
2 \text {. the role of } \\
\text { individuals actively } \\
\text { in Information and } \\
\text { Communication } \\
\text { Technology lessons }\end{array}$ & $\begin{array}{l}\text { Likert } \\
\text { Likert }\end{array}$ \\
\hline & & c. Student Response & $\begin{array}{l}\text { 1. Student responses } \\
\text { when asked questions } \\
\text { by the teacher during } \\
\text { Information and } \\
\text { Communication } \\
\text { Technology lessons } \\
2 \text {. Student responses } \\
\text { in helping teachers }\end{array}$ & $\begin{array}{l}\text { Likert } \\
\text { Likert }\end{array}$ \\
\hline & & d. Learning Outcomes & $\begin{array}{l}\text { 1. individual learning } \\
\text { outcomes of } \\
\text { Information and } \\
\text { Communication } \\
\text { Technology subjects } \\
\text { 2. individual habits in } \\
\text { doing Information } \\
\text { and Communication } \\
\text { Technology tasks }\end{array}$ & $\begin{array}{l}\text { Likert } \\
\text { Likert }\end{array}$ \\
\hline \multirow[t]{4}{*}{2} & $\begin{array}{l}\text { Interest To } \\
\text { Learn }\end{array}$ & 1. Feeling happy & $\begin{array}{l}\text { 1. Individual feelings } \\
\text { towards Information } \\
\text { and Communication } \\
\text { Technology subiects } \\
2 . \quad \text { individual } \\
\text { impressions of } \\
\text { Information and } \\
\text { Communication } \\
\text { Technology subjects } \\
3 . \text { individual opinion } \\
\text { about Information } \\
\text { and Communication } \\
\text { Technology subjects }\end{array}$ & $\begin{array}{l}\text { Likert } \\
\text { Likert } \\
\text { Likert }\end{array}$ \\
\hline & & 2. Student involvement & 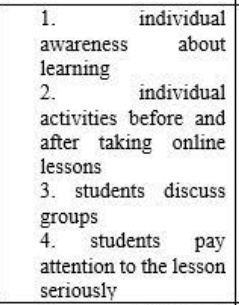 & $\begin{array}{l}\text { Likert } \\
\text { Likert } \\
\text { Likert } \\
\text { Likert }\end{array}$ \\
\hline & & 3. student interest & $\begin{array}{l}1 . \\
\text { curiosity individual } \\
2 . \quad \text { individual } \\
\text { acceptance at the time } \\
\text { of assignment } \\
3 . \text { enthusiastic } \\
\text { individuals in } \\
\text { learning activities }\end{array}$ & $\begin{array}{l}\text { Likert } \\
\text { Likert } \\
\text { Likert }\end{array}$ \\
\hline & & 4. Attention students & $\begin{array}{lr}1 . & \text { individual } \\
\text { attention } & \text { while } \\
\text { participating } & \text { in } \\
\text { learning } & \\
2 . & \text { individual } \\
\text { attention } & \text { when } \\
\text { conducting } & \\
\text { discussions } & \\
\end{array}$ & $\begin{array}{l}\text { Likert } \\
\text { Likert }\end{array}$ \\
\hline
\end{tabular}




\section{METHODS}

The researcher used a quantitative research approach with descriptive method by analyzing and describing the data that had been collected and the survey method in conducting this research.

\subsection{Population and Samples}

The population in this study were all students of SMA Don Bosco 1 class of 2020. The total population of Don Bosco 1 high school students was 153 people.

The sampling technique used in this research is probability sampling technique, namely simple random sampling. [11] Sugiyono explains simple random sampling, the technique of taking sample members is done randomly without paying attention to the standard so that each sample candidate has the same opportunity to represent the population.

Researchers used the Hair et.al formula to obtain a total sample size of 100 samples from 153 Don Bosco 1 high school students. In this study, researchers randomly distributed them to Don Bosco 1 high school students.

\subsection{Method of Collecting Data}

In this study, the data collection method was carried out by distributing questionnaires to 100 respondents of Don Bosco 1 high school students randomly without paying attention to the strata in the population. [12] According to Sudaryono, a questionnaire is a method of collecting data by giving research questions to individuals or groups. Data collection in this study will be carried out by giving written questions to 100 respondents.

\subsection{Data Validity Techniques}

The researcher used IBM SPSS Statistic 24 as a means of the researcher to finding results. The use of IBM SPSS Statistic 24 is used to test the statement indicators of the effectiveness of online learning media variables and learning interest variables by testing validity and reliability. [13] According to Sugiyono, validity is the degree of timeliness between the actual data contained in the research object and the data that can be reported by the researcher, while reliability is how far the results of measurements using the same object will produce the same data (Sudaryono) [14].

\subsection{Data Processing and Analysis Techniques}

In this study, the researcher tested the correlation coefficient to determine the correlation between the independent variable $(\mathrm{X})$ and the dependent variable $(\mathrm{Y})$ and the weak relationship between the independent variable $(\mathrm{X})$ and the dependent variable (Y).

The $t$ test is carried out in order to test whether there is a significant relationship between variable $\mathrm{X}$ and variable $\mathrm{Y}$ and to find out the results or answers to the hypothesis in this study.

\section{FINDINGS AND DISCUSSION}

\subsection{Respondents' Identity}

Table 2 The Gender of Respondents

\begin{tabular}{|c|c|c|}
\hline & Frequency (\%) & $\begin{array}{l}\text { Cumulative } \\
\text { Percentage }\end{array}$ \\
\hline Male & 41 & $41 \%$ \\
\hline Female & 59 & $100 \%$ \\
\hline Total & 100 & \\
\hline
\end{tabular}

Based on table 1. It can be seen that the sample of students in this research survey was mostly obtained from female respondents, namely 59 respondents (59\%) and male gender as many as 41 respondents (41\%).

Table 3 Respondents' Age

\begin{tabular}{|c|c|c|}
\hline & $\begin{array}{c}\text { Frequency } \\
(\%)\end{array}$ & $\begin{array}{l}\text { Cumulative } \\
\text { Percentage }\end{array}$ \\
\hline 16 Years Old & 20 & $20 \%$ \\
\hline 17 Years Old & 45 & $65 \%$ \\
\hline 18 Years Old & 35 & $100 \%$ \\
\hline Total & 100 & \\
\hline
\end{tabular}

Based on table 2, It can be seen that the majority of respondents are 17 years old, namely as many as 45 respondents $(45 \%), 18$ years as many as 35 respondents $(35 \%)$ and respondents aged 16 years as many as 20 respondents $(20 \%)$. 


\subsection{Validity Test}

Table 4 Validity Test Result

\begin{tabular}{|c|c|c|c|}
\hline No & Indicator Herns & $\begin{array}{c}\text { Corrected Hem- } \\
\text { Total } \\
\text { Correlation }\end{array}$ & Result \\
\hline \multirow[t]{9}{*}{1.} & Online Learning Effectiveness: & & \\
\hline & $\begin{array}{l}\text { I got a complete information and } \\
\text { Communication } \\
\text { subject matter }\end{array}$ & 0,537 & Valid \\
\hline & $\begin{array}{l}\text { I get the information and } \\
\text { Communication } \\
\text { subject matter clearly }\end{array}$ & 0,496 & Valid \\
\hline & $\begin{array}{l}\text { I followed the teacher's } \\
\text { explanation carefully in the } \\
\text { Information and Communication } \\
\text { Technology lesson }\end{array}$ & 0,520 & Valid \\
\hline & $\begin{array}{l}\text { I am very active in taking } \\
\text { Information and Communication } \\
\text { Technology lessons }\end{array}$ & 0,501 & Valid \\
\hline & $\begin{array}{l}\text { I often respond when the teacher } \\
\text { asks questions in information } \\
\text { and Communication Technology } \\
\text { lestons }\end{array}$ & 0,000 & Valid \\
\hline & $\begin{array}{l}\text { I often help teachers without } \\
\text { being asked by the teacher in } \\
\text { information and Communication } \\
\text { Technology lessions }\end{array}$ & 0.560 & Valid \\
\hline & $\begin{array}{l}1 \text { got good grades in Information } \\
\text { and Communication Technology }\end{array}$ & 0,479 & Valid \\
\hline & $\begin{array}{l}\text { I was able to anower correctly } \\
\text { when I was asked a question by a } \\
\text { teacher in Information and } \\
\text { Communication Technology }\end{array}$ & 0,522 & Valid \\
\hline \multirow[t]{14}{*}{2.} & Interest To Learn & & \\
\hline & I feel happy with the Information & 0,482 & Valid \\
\hline & $\begin{array}{l}\text { and Communication Technology } \\
\text { subject matter provided by the } \\
\text { teacher }\end{array}$ & & \\
\hline & $\begin{array}{l}\text { I pay attention to the teacher } \\
\text { While explaining the material in } \\
\text { Information and Communication } \\
\text { Technology lessons }\end{array}$ & 0,455 & Valid \\
\hline & $\begin{array}{l}\text { I am silent if I do not understand } \\
\text { the lessons of information and } \\
\text { Communication Technology }\end{array}$ & 0,420 & Valid \\
\hline & $\begin{array}{l}\text { I was busy alone when the } \\
\text { teacher taught in information and } \\
\text { Communication Technology } \\
\text { lessons }\end{array}$ & 0,580 & Valid \\
\hline & $\begin{array}{l}\text { I am excited to learn because the } \\
\text { teacher teaches in a fun way }\end{array}$ & 0,533 & Valid \\
\hline & $\begin{array}{l}\text { It s more fun to play than } \\
\text { studdying at hoene during online } \\
\text { classes on information and } \\
\text { Communication Technology } \\
\text { lessons }\end{array}$ & 0,389 & Valid \\
\hline & $\begin{array}{l}\text { I discussed with my group about } \\
\text { information and Communication } \\
\text { Technology lessons }\end{array}$ & 0,504 & Valid \\
\hline & $\begin{array}{l}\text { I was not excited for the online } \\
\text { class of Information and } \\
\text { Communication Technology } \\
\text { because the teacher was boting }\end{array}$ & 0,407 & Valid \\
\hline & $\begin{array}{l}\text { I prefer to have my friends do my } \\
\text { information and Communication } \\
\text { Technology assignments }\end{array}$ & 0,484 & Valid \\
\hline & $\begin{array}{l}\text { The lessons given by Information } \\
\text { and Communication Technology } \\
\text { teachers are very boring }\end{array}$ & 0,495 & Valid \\
\hline & $\begin{array}{l}\text { I really like to ask questions } \\
\text { during online classes on } \\
\text { Information and Cormmunication } \\
\text { Technology lessoris }\end{array}$ & 0,506 & Valid \\
\hline & $\begin{array}{l}\text { I am really looking forward to the } \\
\text { time the Information and } \\
\text { Communication Technology } \\
\text { online class will start }\end{array}$ & $0,5=6$ & Valid \\
\hline
\end{tabular}

This research questionnaire has 8 statements for variable $\mathrm{X}$ and 12 statements for variable $\mathrm{Y}$ which are distributed to 100 respondents, then the results of the questionnaire data are used to perform validation tests using the assistance of the IBM SPSS Statistic 24 program.

From the results of this validity test, the researcher obtained $\mathrm{r}$-table of 0.195 . Based on the test results in table 3. it can be concluded that the data are valid and suitable for use. This decision is based on if $r$-count $>$ r-table can be declared valid.

\subsection{Reliability Test}

Table 5 Reliability Test Result

\begin{tabular}{|c|c|c|}
\hline Variable & Cronbach's Alpha & Result \\
\hline $\begin{array}{c}\text { Online Learning } \\
\text { Effectiveness }\end{array}$ & 0,853 & Reliable \\
\hline Interest To Learn & 0,775 & Reliable \\
\hline
\end{tabular}

In the table of reliability test results, it shows that the Cronbach's alpha value of variable $\mathrm{X}$ is $0.853(>0.70)$ and variable $\mathrm{Y}$ is 0.775 (>0.70). So based on the table above, variables $\mathrm{X}$ and $\mathrm{Y}$ are declared reliable and fit for use.

\subsection{Correlation Coefficient}

Table 6 t-Test Result

\begin{tabular}{|c|c|c|c|}
\hline \multicolumn{2}{|l|}{} & $\begin{array}{c}\text { Online Learning } \\
\text { Effectiveness (X) }\end{array}$ & Interest To Learn(Y) \\
\hline $\begin{array}{c}\text { Online } \\
\text { Learning } \\
\text { Effectiveness }\end{array}$ & $\begin{array}{c}\text { Pearson Correlation } \\
\text { Sig. (2-tailed) }\end{array}$ & 1 & $.375^{* *}$ \\
(X) & N & 100 & .000 \\
\hline Interest To & Pearson Correlation & $.375^{* *}$ & 100 \\
Learn (Y) & Sig. (2-tailed) & .000 & 1 \\
& N & 100 & 100 \\
\hline
\end{tabular}

**. Correlation is significant at the 0.01 level (2-tailed)

Based on the results of the correlation coefficient analysis in table 4.13 , it is known that the significance value is 0.00 , which means that if the significance value is $<0.05$, it is correlated, then it can be concluded that the variables $\mathrm{X}$ and $\mathrm{Y}$ can be correlated. In the table above, it can also be seen that the value of the Pearson correlation is 0.375 which means it has a weak correlation. 


\section{5 t-Test}

Table 7 t-Test Result

\begin{tabular}{|c|c|c|c|c|c|c|}
\hline \multicolumn{7}{|c|}{ Coefficients $^{a}$} \\
\hline & & \multicolumn{2}{|c|}{$\begin{array}{l}\text { Unstandardiz } \\
\text { ed } \\
\text { Coefficients }\end{array}$} & \multirow{2}{*}{$\begin{array}{c}\begin{array}{c}\text { Standardiz } \\
\text { ed } \\
\text { Coefficient } \\
\text { s }\end{array} \\
\text { Beta }\end{array}$} & \multirow{2}{*}{$t$} & \multirow{2}{*}{ Sig. } \\
\hline \multicolumn{2}{|r|}{ Model } & $\beta$ & $\begin{array}{c}\text { Std. } \\
\text { Error }\end{array}$ & & & \\
\hline \multirow[t]{2}{*}{1} & (Constant) & $\begin{array}{r}21.68 \\
1\end{array}$ & 4.530 & & 4.786 & .000 \\
\hline & $\begin{array}{l}\text { Online } \\
\text { Learning } \\
\text { Effectiveness }\end{array}$ & .564 & .141 & .375 & 3.999 & .000 \\
\hline
\end{tabular}

Researchers used a partial testing technique (t-test) in order to determine whether there was a significant relationship between variable $\mathrm{X}$ and variable $\mathrm{Y}$.

From the results of this study, it can be seen that the $t$ value of the effectiveness of online learning is $3.999(>1.987)$ and the significant value in variable $\mathrm{X}$ on variable $\mathrm{Y}$ is $0.000(<$ 0.05), which means that it can be concluded that $\mathrm{H}_{1}$ 'effectiveness of online learning' is significantly effective on student learning interest. SMA Don Bosco 1 subject in Information and Communication Technology 2020 'was accepted and $\mathrm{H}_{0}$ was rejected.

\section{CONCLUSIONS}

This study uses quantitative methods using a questionnaire as a data collection tool. The researcher get the results of all data processing using the SPSS for windows version 24 program.

Based on the results of the research, the results of the analysis and discussion that have been described, the researcher can conclude that online learning media is quite effective in the learning interest of Don Bosco 1 High School students in Information and Communication Technology lessons in 2020. This is known through the $t$ test results in table 5 that $\mathrm{H} 1$ which reads' there is a relationship between the effectiveness level of online learning media and the learning interest of Don Bosco 1 High School students in the Information and Communication Technology subject in 2020 'is accepted and $\mathrm{HO}$ which reads' there is no relationship between the level of effectiveness of online learning media on the learning interest of Don Bosco 1 High School students Information and Communication Technology subjects in 2020 'were rejected.

\section{ACKNOWLEDGMENT}

The researchers thanks to God Almighty because the researchers were able to complete this article through the blessings of His grace. The author also thanks the Faculty of Communication at Tarumanagara University for giving the researcher the opportunity to make this journal. This research journal would not be complete without the assistance, advice and support provided by the supervisor, friends, and related people to the researcher.

\section{REFERENCES}

[1] Rahmanto, Hari, 2011. Pengaruh Latar Belakang Pekerjaan Orang Tua dan Bimbingan Orang Tua Terhadap Minat Berwiraswasta Siswa Kelas XI Teknik Otomotif SMKN 2 Pengasih. Jurnal Fakultas Teknik: UNY.

[2] Ramadhani, M. (2012). Efektivitas Penggunaan Media Pembelajaran E-Learning Berbasis Web pada Pelajaran Teknologi dan Komunikasi terhadap Hasil Belajar Siswa Kelas X SMA Negeri 1 Kalasan. S1 thesis, UNY.

[3] Kristianti, T., \& Erdiansyah, R. (2020). Pengaruh Electronic Word of Mouth, Tingkat Kepercayaan Konsumen Dan Minat Kunjungan Wisata Kuliner Kota Bogor. Prologia, 4(2), 393-401.

[4] Kusuma, Y.A. (2020). Efektivitas penggunaan aplikasi Quizizz dalam pembelajaran daring (online) fisika pada materi usaha dan energi kelas X MIPA di SMA Masehi Kudus tahun pelajaran 2019/2020. Skripsi thesis, Sanata Dharma University.

[5] Mardiasmo, (2017). Perpajakan. Yogyakarta: Andi

[6] Azhar, Arsyad. 2011. Media Pembelajaran. Jakarta : Rajawali Pers

[7] Ardiansyah, I. (2013). Eksplorasi Pola Komunikasi dalam Diskusi Menggunakan Moddle pada Perkuliahan Simulasi Pembelajaran Kimia. Bandung: Universitas Pendidikan Indonesia.

[8] Rahmanto, Hari, 2011. Pengaruh Latar Belakang Pekerjaan Orang Tua dan Bimbingan Orang Tua Terhadap Minat Berwiraswasta Siswa Kelas XI Teknik Otomotif SMKN 2 Pengasih. Jurnal Fakultas Teknik: UNY. 
[9]. Bahri, Djamarah,S. (2011). Psikologi Belajar, Jakarta: PT. Rineka Cipta

[10] Hamalik, Oemar. (2010). Proses Belajar Mengajar. Jakarta: PT Bumi Aksara

[11] Sugiyono (2012). Metode Penelitian Kuantitatif Kualitatif dan R\&D. Bandung: Alfabeta

[12] Sudaryono. (2018). Metodologi Penelitian. Depok: Rajawali Pers.

[13] Sugiyono (2012). Metode Penelitian Kuantitatif Kualitatif dan $R \& D$. Bandung: Alfabeta

[14] Sudaryono. (2018). Metodologi Penelitian. Depok: Rajawali Pers. 